\title{
SOSIALISASI PENGOLAHAN LINDI MENJADI PUPUK CAIR DI TPS-3R KELURAHAN TALANG KELAPA KECAMATAN ALANG-ALANG LEBAR PALEMBANG SUMATERA SELATAN
}

\author{
Eka Sri Yusmartini ${ }^{1}$, Mardwita $^{2}$, Innike Abdillah Fahmi ${ }^{3}$ \\ ${ }^{1,2}$ Program Studi Teknik Kimia, Universitas Muhammadiyah Palembang \\ ${ }^{1,2}$ Program Studi Magister Teknik Kimia, Universitas Muhammadiyah Palembang \\ ${ }^{3}$ Program Studi Teknik Kimia, Universitas Muhammadiyah Palembang \\ e-mail: eka.yusmartini@gmail.com,wiwitdiita@gmail.com,fahmi.innike@gmail.com

\begin{abstract}
Abstrak
Meningkatnya pertumbuhan penduduk dan aktifitasnya, memberi kontribusi significan pada peningkatan sampah. Bank Sampah merupakan usaha masyarakat bersama dengan pemerintah yang memiliki fungsi sebagai media edukasi bagi masyarakat bagaimana memelihara lingkungan dan mengelola sampah. Permasalahan mitra (TPS3R) KSM Maju Jaya Kelurahan Talang Kelapa adalah adanya lindi dari proses pengomposan sampah organikyang tidak diolah, hanya dibiarkan begitu saja, sehingga menyebabkan timbulnya bau di sekitar TPS-3R. Metode yang digunakan dalam program kemitraan masyarakat (PKM) adalah dengan pendekatan terhadap mitra untuk memberikan pandangan tentang perlunya diversifikasi produk untuk pengolahan lindi yang dihasilkan dalam proses pengomposan. Pendampingan dan pelatihan dilakukan terhadap mitra dalam proses pengolahan lindi menjadi pupuk cair. Hasil dari kegiatan adalah tersedianya alat untuk proses pengolahan lindi menjadi pupuk cair, meningkatnya ketrampilan mitra dalam memanfaatkan limbah usaha menjadi produk pupuk organik cair dan meningkatkan pendapatan mitra. Kelangsungan produksi pupuk organik cair berkelanjutan dengan adanya ketrampilan dari mitra dan bahan baku yang tersedia, berupa lindi.
\end{abstract}

Kata kunci: sampah organik, TPS-3R, kompos,lindi, pupuk cair.

\begin{abstract}
The increasing population growth and its activities, causes an increase in household waste. Waste Bank is a community effort together with the government which functioning as an educational media for the community how to maintain the environment and manage waste. The problem of partners (TPS-3R) KSM Maju Jaya Talang Kelapa Village is the lindi of the process of composting organic waste that is not processed, only left alone, causing the onset of odors around TPS-3r. The method used in the community partnership program (PKM) is to approach partners to provide an understanding of the need to diversify products for the processing of lindi produced in the composting process. Mentoring and training is carried out on partners in the process of processing lindi into liquid fertilizer. The result of the activities is the availability of tools for the processing of lindi into liquid fertilizer, increasing the skills of partners in utilizing business waste into liquid organic fertilizer products and increasing the income of partners. The continuity of liquid organic fertilizer production is sustainable with the skills of partners and raw materials available, in the form of lindi.
\end{abstract}

Keywords : organic waste, TPS-3R, compost, leachate, liquid fertilizer.

\section{PENDAHULUAN}

Meningkatnya pertumbuhan

penduduk dan aktifitasnya, memberi kontribusi significan pada peningkatan sampah. Cara pengolahan sampah yang umum di Indonesia adalah dengan membawa sampah ke Tempat Pembuangan Akhir Sampah ( Peraturan Pemerintah Nomor 81 Tahun 2012) tentang pengelolaan Sampah Rumah Tangga dan 
Sampah sejenis Sampah Rumah Tangga. Kota Palembang dengan jumlah penduduk tahun 2019 sebanyak 1,6 juta jiwa (Badan Pusat Statistik, 2020) menghasilkan timbulan sampah 1.200 ton sampah per harinya. Kebijakan Kementerian Lingkungan Hidup Nomor 13 Tahun 2012 tentang pengelolaan sampah melalui metode $3 \mathrm{R}$ yang dilakukan di TPS merupakan suatu usaha untuk mengurangi timbulan sampah ke TPA.

Wilayah Kota Palembang terdiri dari 16 wilayah kecamatan dan 107 kelurahan, dimana kota Palembang merupakan salah satu kota yang terpilih untuk mengembangkan metode 3 - $R$ dalam pengelolaan sampah. Kelompok swadaya masyarakat Maju Jaya merupakan salah satu percontohan untuk mengembangkan metode 3 - R di kota Palembang.

Kelompok Swadaya Masyarakat Maju Jaya sudah berdiri sejak tahun 2013, yang kemudian membentuk Bank Sampah Sakura pada tahun 2015 yang diprakarsai oleh Kepala Sekolah, RT, Lurah dan Camat. Pada tanggal 1 Januari 2016, TPS3R Kelompok Swadaya Masyarakat terbentuk, dimana lokasi TPS-3R berada berdekatan dengan Bank Sampah Sakura, seperti ditampilkan pada Gambar 1.

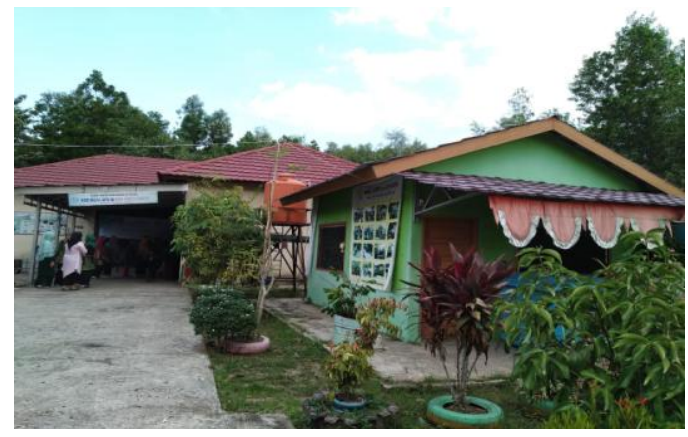

Gambar 1. Lokasi TPS 3 -R dan Bank Sampah Sakura.

Bank Sampah dan TPS $3-\mathrm{R}$ merupakan kegiatan yang saling bersinergi. Bank Sampah merupakan usaha masyarakat bersama dengan pemerintah memiliki fungsi sebagai media edukasi bagi masyarakat bagaimana memelihara lingkungan dan mengelola sampah. TPS 3 -R Kelompok Masyarakat (KSM) Maju Jaya sudah melaksanakan kegiatan untuk metode 3 - R tersebut. Hasil dari proses 3 - $\mathrm{R}$ berupa kompos dan produk kerajinan tangan berbahan bekas.

Sampah organik yang dipisahkan dari sampah anorganik menjadi bahan baku untuk pembuatan kompos. Menurut Wiratini dkk (2014), kompos organik yang dihasilkan dapat memperbaiki struktur tanah serta memperbesar kemampuan tanah menyerap air dan menahan unsur hara. Sampah organik tersebut didapat dari $350 \mathrm{KK}$ dari 18 RT yang ada di kelurahan Talang Kelapa. Sampah Organik yang diserahkan oleh warga tersebut berkisar antara $30-60$ kilo perhari. Sampah organik adalah jenis sampah yang mendominasi sampah rumah tangga Kota Palembang (Mardwita dkk, 2018).

Permasalahan mitra adalah adanya lindi dari proses pengomposan yang tidak diolah, hanya dibiarkan saja, dan menyebabkan bau disekitar TPS. Lindi adalah cairan yang merupakan hasil dari degradasi sampah yang dapat menimbulkan pencemaran jika tidak diolah sebelum dibuang kelingkungan (Eka dkk, 2013). Selama ini, lindi yang dihasilkan dalam proses pengomposan di TPS- $3 \mathrm{R}$ Maju Jaya tidak diolah, hanya dibiarkan saja mengalir ke selokan yang ada, tidak dimanfaatkan maupun diolah sehingga dapat mencemari lingkungan. Sehubungan dengan permasalahan mitra tersebut, tim kegiatan program kemitraan masyarakat (PKM), akan melakukan kegiatan untuk mengolah lindi yang dihasilkan dari pengomposan sampah menjadi pupuk cair, sehingga dapat meningkatkan produksi dari TPS-3 $R$, tidak hanya menghasilkan kompos, tapi juga menghasilkan produk pupuk cair menggunakan lindi dari hasil pengomposan sampah organik.

Kegiatan tersebut akan dilakukan dengan membuat alat dan melakukan pendampingan dan pelatihan tentang penggunaan alat yang ada, dan juga bagaimana pengemasan produk pupuk cair yang dihasilkan. Keunggulan dari program kemitraan ini adalah diversifikasi produk yang dihasilkan, berupa pupuk cair dari hasil pengolahan kompos yang selama ini sudah dilakukan mitra. Selain itu dengan adanya diversifikasi produk diharapkan 
terjadi peningkatan ketrampilan mitra dan juga meningkatkan pendapatan mitra.

\section{METODE}

Metode yang digunakan dalam program kemitraan masyarakat (PKM) ini adalah dengan pendekatan terhadap mitra untuk memberikan pandangan tentang perlunya diversifikasi produk untuk pengolahan lindi. Mitra bersedia untuk melakukan diversifikasi tersebut.

Selanjutnya tim melakukan proses pengukuran pemasangan alat untuk mengumpulkan lindi dari hasil pengomposan. Perancangan alat dilakukan sesuai kondisi ditempat pengomposan. Alat untuk mengolah lindi yang sudah terkumpul juga dirancang sesuai kebutuhan, tergantung dari jumlah lindi yang akan terkumpul

Tahap selanjutnya adalah melakukan pendampingan dan pelatihan bagaimana mengolah lindi menjadi pupuk cair menggunakan alat yang sudah disiapkan, dan juga bagaimana proses pengemasan sehingga dapat dipasarkan.

Evaluasi keberhasilan program pemberdayaan mitra dilakukan dengan metode quisioner, dengan cara memberikan beberapa pertanyaan yang dilakukan pada saat sebelum dan sesudah kegiatan dilakukan. Adapun yang menjadi tolok ukur evaluasi ini adalah pemahaman masyarakat terhadap materi pendampingan dan pelatihan pembuatan pupuk organik cair.

\section{HASIL DAN PEMBAHASAN}

Pelaksanaan pengabdian dilakukan dengan beberapa tahap. Tahap pertama sosialisasi dengan mitra untuk mengenalkan bahwa lindi dari hasil pengomposan sampah organik bisa diolah menjadi pupuk cair, karena lindi mengandung nutrien, bahan organik yang cukup tinggi yang dapat meningkatkan aktivitas mikroorganisme dalam mendegradasi sampah organik (Yommi dan Ichsan, 2016).

Mitra dalam hal ini menyetujui sekali dengan rencana tersebut. Diskusi dan rencana untuk menerapkan proses tersebut dilakukan dengan baik dan intensif baik secara langsung ataupun lewat media elektornik, dikarenakan kondisi pandemi Covid-19. Diskusi tentang rancangan alat dilakukan langsung di lokasi, dimana antusias mitra sangat besar, terlihat dari kehadiran dan kemauan mitra untuk menambah pengetahuan tentang pengolahan lindi menjadi pupuk cair. Selama ini mitra hanya mengabaikan keberadaan lindi, karena belum memahami kalau lindi bisa diolah menjadi pupuk cair. Gambar 2 memperlihatkan rangkaian kegiatan sosialisasi dan pemasangan alat untuk pengomposan, dimana lindi yang dihasilkan akan diolah menjadi pupuk cair.

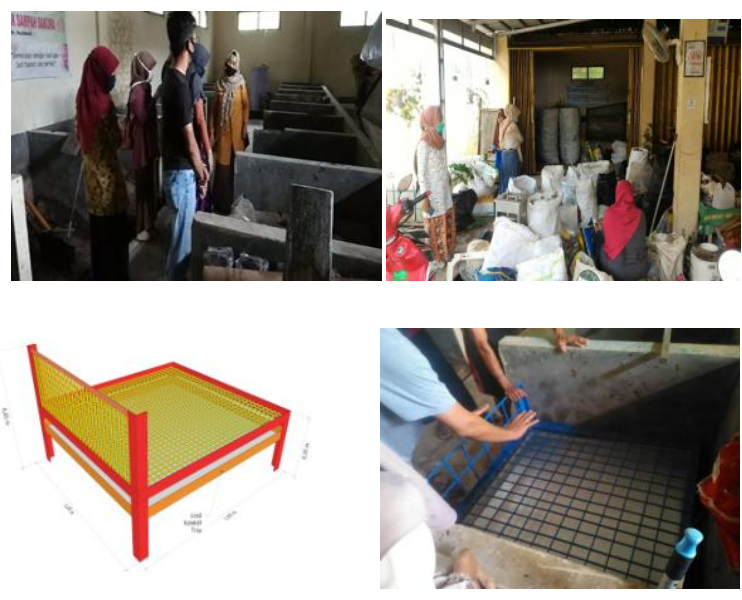

Gambar 2. Sosialisasi, disain alat dan pemasangan alat untuk pengumpul lindi

Pemasangan alat pengumpul lindi pada tempat yang sudah terukur, dilakukan pada tanggal 4 Mei 2020. Dengan alat ini, lindi hasil pengomposan dapat dikumpulkan untuk diolah menjadi pupuk cair. Sebelum ada alat penampung atau meja komposter ini, pengomposan dilakukan langsung dilantai tidak ada penampung air lindi.

Alat untuk membuat membuat pupuk cair disiapkan sesuai dengan kapasitas pengomposan. Dimana lindi yang terkumpul akan dilakukan proses fermentasi dengan komposisi sesuai dengan banyaknya lindi yang terkumpul. Gambar 3 menampilkan pengomposan sebelum dan sesudah ada alat pengumpul lindi, dan alat yang digunakan untuk proses pembuatan pupuk cair. 

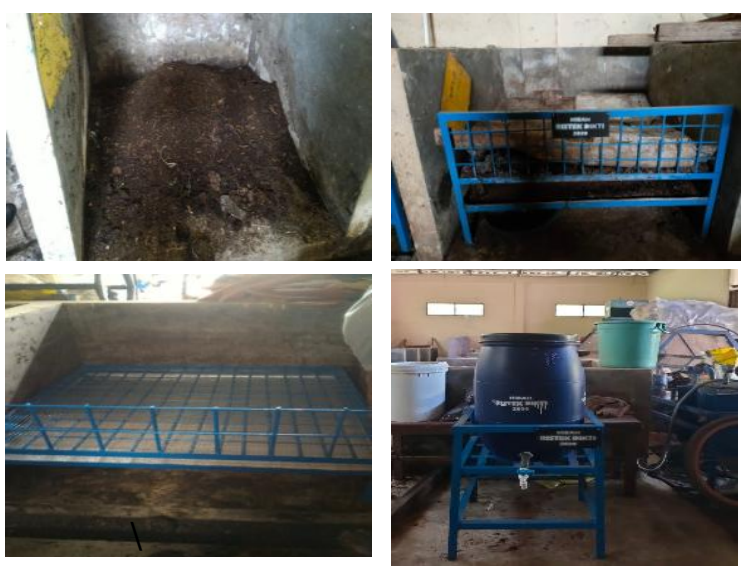

Gambar 3. Alat -alat yang digunakan dalam proses pembuatan pupuk organik cair.

Selanjutnya Tim PKM melakukan pendampingan dan pelatihan pembuatan pupuk cair. Untuk pembuatan pupuk cair, diberikan petunjuk berupa catatan, mengenai perbandingan antara lindi, bioaktivator dan juga cara mengurangi bau pada pupuk cair yang dihasilkan. Proses fermentasi dilakukan secara anaerob. Pupuk organik cair yang dihasilkan secara anaerob memiliki bau yang tidak sedap, dimana ada 2 jenis gas yang menjadi penyebab bau tersebut, yaitu $\mathrm{NH}_{3}$ (amoniak) dan $\mathrm{H}_{2} \mathrm{~S}$ atau gas sulfida (Nurhasanah dan Hedi, 2013). Hal ini sejalan dengan hasil yang didapatkan lyandri (2011), yang menyatakan bahwa gas gas tersebut merupakan produk samping dari proses peruraian bahan organik secara anaerobik oleh mikroorganisme.

Proses fermentasi lindi menjadi pupuk cair dilakukan dengan perbandingan pemakaian air kapur untuk mengurangi kepekatan warna dari lindi sebanyak $15 \mathrm{~mL}$ per satu liter lindi, kemudian diaduk rata. Setelah itu ditambahkan bioaktivator sebanyak $10 \mathrm{~mL}$ per satu liter lindi. Bioaktifator yang digunakan dibuat sendiri oleh mitra, merupakan bioaktivtor dari bahan organik, yang selama ini digunakan untuk pembuatan kompos. Pengadukan dilakukan setiap hari selama 7 hari, supaya larutan tercampur rata. Pada hari ke 8 dilakukan penambahan sereh atau jeruk lemon untuk mengurangi bau pada proses fermentasi. Kemudian dilakukan lagi proses fermentasi selama 21 hari.
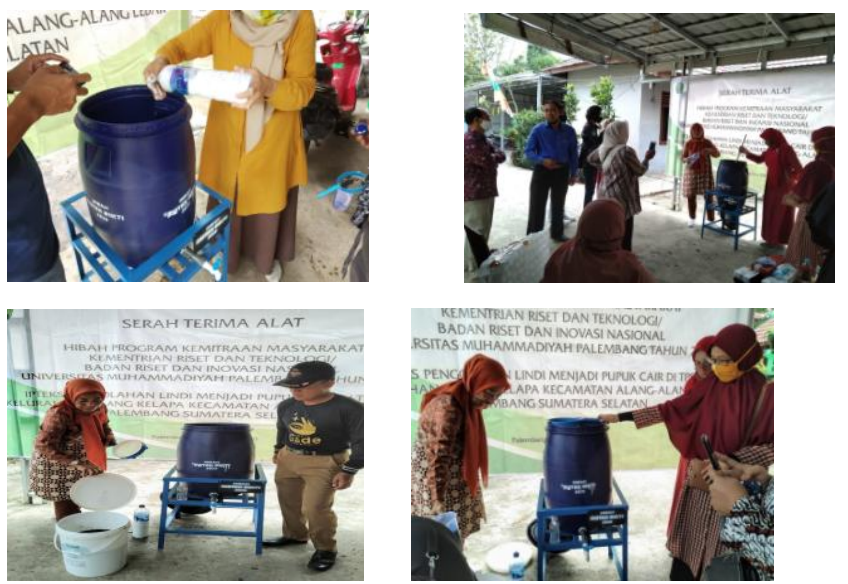

Gambar 4. Pendampingan dan pelatihan pembuatan pupuk cair

Pendampingan panen hasil pupuk cair dan juga pemakaian secara langsung dilakukan pada tanaman yang ada di TPS-3 R KSM Majujaya sebagai mitra. Pemakaian pupuk cair dilakukan dengan perbandingan $10 \mathrm{~mL}$ pupuk cair dalam I liter air, dan disemprotkan ke tanaman dengan penyemprotan seminggu sekali. Hasil pemakaian yang dilakukan terhadap tanaman menunjukkan tanaman yang menggunakan pupuk lebih tinggi daripada yang tidak menggunakan pupuk cair yang dihasilkan. Manfaat lain dari pupuk cair yang dihasilkan dapat dapat digunakan sebagai bioaktivator dalam proses pengomposan (Evelin, 2016).
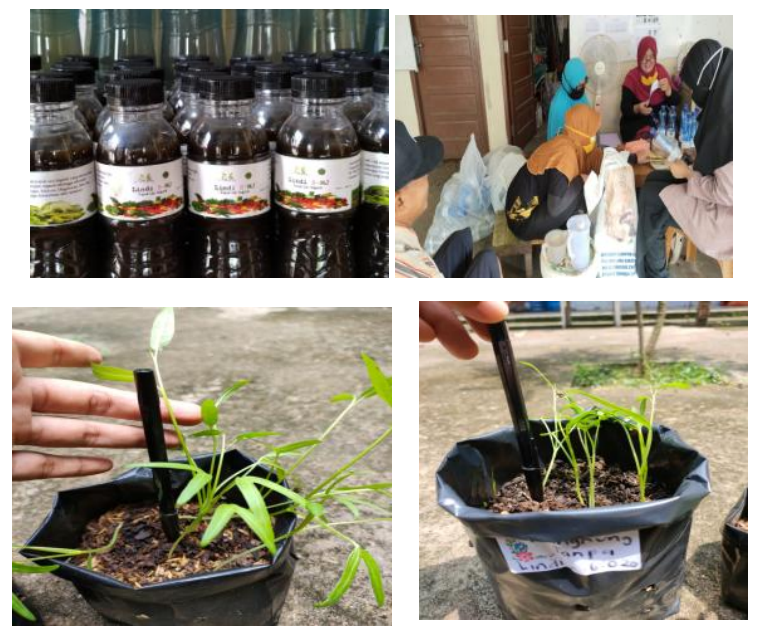

Gambar 5. Produksi pupuk cair dan pemakaian pupuk pada tanaman

Evaluasi keberhasilan program kemitraan menunjukkan peningkatan yang 
baik sekali. Dari hasil evaluasi berdasarkan quis sebelum dan sesudah sosialisasi, pendampingan dan pelatihan, mitra telah mempunyai ketrampilan dalam mengolah lindi menjadi pupuk cair dengan cara anaerob. Pemahaman pembuatan pupuk cair sebelum kegiatan dilakukan sebesar $30 \%$ dan meningkat menjadi $92 \%$ setelah kegiatan dilakukan.

\section{KESIMPULAN}

Keberhasilan mitra dalam mengolah lindi menjadi pupuk organik cair, merupakan alternatif untuk memanfaatkan limbah, menyediakan pupuk cair sebagai bentuk diversifikasi produk kompos yang sudah dilakukan, melestarikan lingkungan serta meningkatkan produksi dan pendapatan mitra. Produk pupuk cair ini diharapkan akan berjalan terus, seiring dengan produk kompos dan akan dibina terus sehingga produk pupuk organik cair dapat berkesinambungan.

\section{UCAPAN TERIMAKASIH}

Tim Pengabdian mengucapkan terima kasih kepada Dirjen Penguatan Riset Penelitian dan Pengabdian Kepada Masyarakat Kemenristek Dikti RI Tahun Anggaran 2020, pihak yang telah memberi dukungan finansial terhadap pelaksanaan kegiatan ini. Bapak Rektor Universitas Muhammadiyah Palembang dan jajarannya serta LPPM Universitas Muhammadiyah Palembang yang telah memfasilitasi pelaksanaan PKM ini, dan Tim PKM juga mengucapkan terimakasih kepada Pengurus dan anggotaTPS- 3R Kelurahan Talang Kelapa, Kecamatan Alang-Alang Lebar Palembang Sumatera Selatan sebagai mitra PKM.

\section{DAFTAR PUSTAKA}

Badan Pusat Statistik.2020.Jumlah Penduduk Menurut Kecamatan di Kota Palembang tahun 2019.pp.3558, doi:10.1055/s-2008-1040325
Eka SY, Dedi S, Ridwan, Marsi and Faizal,2013. Characteristic of Leachate at Sukawinatan Landfill, Palembang, Indonesia, Journal of Physics, Conference Series 423 (2013)012048

Evelin N, Edelberth D, Candar DW.2016. Pemanfaatan Lindi Sebagai EM4 dalam Proses Pengomposan, Temu IImiah IPLBI.

lyandri, 2011. Dampak Pencemaran Limbah Padat. Diambil dari, http://id.shvoonq.com/exactsciences/2097337-dampakpencemaran=limbah-padat/

Mardwita, Eka SY, Ummi K, Rifdah, Zuber A. 2018. Penyuluhan Pembuatan Kompos dari Limbah Rumah Tangga Menggunakan Komposter di Kelurahan Kebun Bunga, Palembang, Jurnal Widya Laksana, Volume 7, No.2.

Nurhasanah, Hedi. H, 2013. Pemanfaatan Sereh (Cymbopogon Cytratus) Dalam Menurunkan Bau Pada Pupuk Organik Cair Dan Potensinya Dalam Meningkatkan Produksi Tanaman Cabai (Capsicum Annum), Jurnal Matematika, Sains dan Teknologi, Volume 14 Nomor 1,hal.37-47

Peraturan Pemerintah Republik Indonesia Nomor 81 Tahun 2012 Tentang Pengelolaan Sampah Rumah Tangga dan Sampah Sejenis Sampah Rumah tangga.

Wiratini N.M, Lasia L.K, Maryam S,dan Retug N.2014. Pelatihan Membuat Kompos Dari Limbah Pertanian di Subak Telaga Desa Mas Kecamatan Ubud, Jurnal Widya Laksana, Vol.3 (2):70-88

Yommi D, Ichsan A, 2016. Studi Optimasi Kematangan Kompos Dari Sampah Organik Dengan Penambahan Bioaktivator Limbah Rumen Dan air Lindi 